\title{
KEGIATAN OLAHRAGA DAN KESINAMBUNGAN ENERGI
}

Oleh :

\author{
Eka. Supriatna ${ }^{1}$ \\ Jurusan Ilmu Keolahragaan \\ Email : ekasupriatna@ymail.com
}

\begin{abstract}
Abstrak : Di lapangan seorang pelatih sukar mengukur seberapa besar energi yang sudah dikeluarkan oleh seorang atlit, biasanya penanda yang paling mudah adalah dengan mengukur denyut jantung di pergelangan tangan. Namun itu tidak cukup sebagai penanda seberapa besar energi yang sudah digunakan, tetapi harus dikaji lebih dalam melalui kajian ilmu faal. Berbicara olahraga tidak terlepas dari sistem energi yang digunakan. Karena dalam aktivitas olahraga terjadi sebuah perubahan energi kimia menjadi energi mekanik. Oleh karena itu, bagi yang berkecimpung dalam bidang olahraga merupakan syarat mutlak untuk mengetahui persediaan sistem energi. Pengetahuan ini tidak hanya penting untuk pelatih, guru pendidikan jasmani, tetapi juga penting bagi atlit. Kita mengenal beberapa macam sistem energi yang berhubungan dengan aktivitas olahraga antara lain; sistem ATP-PC, sistem asam laktat dan sistem aerobik yang semuanya itu sebagai penyedia kebutuhan energi dalam aktivitas olahraga.
\end{abstract}

Kata Kunci : kegiatan olahraga, kesinambungan energi.

Abstract: In the field, a coach is difficult to measure how much energy has been issued by an athlete which the most convenient marker usually is to measure heart rate wrist. It was not enough to be a marker of how much energy is already used, but is should be studied more deeply through the study of physiology. Talking about sport, it can not be separated from the energy system used. Because in sporting activities, there was a change from the chemical energy into mechanical energy. Therefore, for those working in the field of sport is absolutely necessary to know the energy supply system. This change is not only important for coaches, physical education teachers, but also important for athletes. We know some kind of energy systems associated with sports activities, such as the ATP-PC system, a system

${ }^{1}$ Eka Supriatna adalah dosen Jurusan Pendidikan Ilmu Keolahragaan FKIP 
of lactic acid and all the aerobic system as a provider of energy needs in sporting activities.

Key words : sports, energy sustainability.

\section{Pendahuluan}

Sumber energi yang digunakan pada latihan fisik, berasal dari Adenosin TriPhospate (ATP-CP), glikolisis anaerobik, dan sistem aerobik. Dalam olahraga tidak akan dapat murni digunakan salah satu sistem energi, akan terjadi bergantian kedua-keduanya (aerobik dan anaerobik). Namun masing-masing olah raga memiliki kekhususan energi yang paling utama digunakan, yaitu yang biasanya disebut sistem energi utama.

Pada permainan olahraga ada beberapa aktivitas yang menggunakan sistem energi ATP-CP, glikolisis anaerobik, dan sistem aerobik. Namun ditinjau secara utama olahraga tersebut menggunakan sistem energi anaerobik yang berasal dari ATP-PC sebesar $70 \%$ (Brooks, 1987:230).

Terdapat tiga proses untuk penggunaan energi dari ATP, yaitu:

\subsection{Sistem ATP-CP (Sistem fosfagen).}

Dalam sistem ini resintesis ATP hanya berasal dari satu senyawa yaitu kreatin fosfat (CP). Sistem ATP - CP hanya mampu menyediakan energi untuk aktivitas kurang dari 30 detik. Pada permainan olahraga, sistem energi ATP-CP dapat dilihat hampir pada semua aktivitas seperti: smash, forehand, backhand, steping atau melangkah, dan service. Semua aktivitas pada permainan olahraga secara dominan dilakukan dengan frekuensi yang tinggi, itensitas yang sangat tinggi dan setiap gerakan dilakukan dengan kecepatan yang tinggi pula dalam waktu yang sangat singkat.

ATP yang tersedia dalam otot sangat terbatas jumlahnya. Kalau kita ingin bahwa otot itu dapat berkontraksi berulang-ulang, maka ATP yang digunakan otot harus dibentuk kembali. Untuk itu diperlukan suatu senyawa yang dapat membentuk ATP dengan cepat. Senyawa tersebut adalah fosfokreatin. Fosfokreatin terdapat juga dalam otot. Oleh karena ATP dan CP mengadung senyawa fosfat $(\mathrm{P})$, maka sistem ini biasanya disebut sebagai sistem fosfagen. Apabila CP pecah akan keluar energi. Pemecahan tersebut tidak memerlukan oksigen. $\mathrm{CP}$ ini jumlahnya hanya sedikit, tetapi $\mathrm{CP}$ merupakan sumber energi yang tercepat untuk membentuk ATP kembali. 


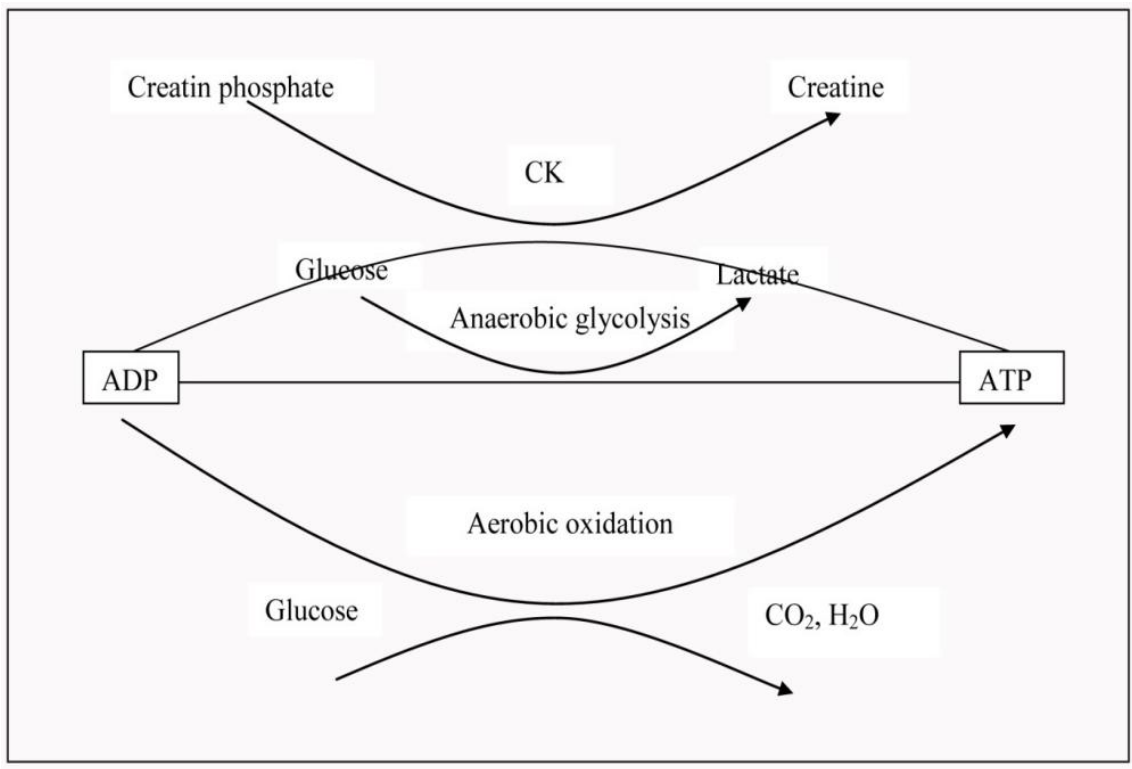

Gambar 1 Jalur pembentukan ATP dalam otot (Mattner, 1988) Sistem ATP-CP atau sistem fosfagen

Tanpa sistem ini gerakan yang cepat dan kuat tidak mungkin dapat dilakukan dengan sempurna, sebab aktivitas semacam itu memerlukan pasokan energi ATP yang cepat. Sistem fosfagen memenuhi keperluan tersebut karena:

a. Tidak tergantung pada reaksi kimia yang panjang.

b. Tidak membutuhkan oksigen.

c. ATP-CP tertimbun dalam mekanisme kontraktil otot

Energi ini cepat habis, untuk membentuk ATP lagi kalau cadangan CP habis adalah pemecahan glukosa tanpa oksigen yang disebut glikolisis anaerobik.

Proses resintesis ATP oleh CP dapat digambarkan sebagai berikut:

creatine kinase

$\mathrm{CP} \Rightarrow \mathrm{C}+\mathrm{Pi}+$ Energi, energi dan fosfat ini digunakan untuk membentuk ATP kembali dari ADP, seperti berikut ini

$\mathrm{ADP}+\mathrm{Pi}+$ Energi $\Rightarrow \mathrm{ATP}$ 
Sistem fosfogen bagi permainan adalah sangat penting, sebab dalam permainan olahraga sebelum adanya ketersediaan oksigen di jaringan tercukupi, pertama kali yang digunakan adalah sistem fosfogen. Demikian juga dengan aktifitas fisik (Olahraga) yang memperlukan gerakan yang cepat seperti pada permainan olahraga dalam waktu yang singkat tentu mengandalkan simpanan fosfogen dalam penyediaan energinya. Tanpa adanya simpanan fosfogen dan sistem pemanfaatan yang baik gerakan yang cepat dengan intensitas tinggi tidak mungkin terjadi. Sebab gerakan yang cepat memperlukan pasokan energi yang cepat pula, hanya melalui sistem fosfogen yang sangggup memenuhinya

\subsection{Sistem glikolisis Anaerobik atau sistem asam laktat.}

Sistem ini menyediakan ATP dari pemecahan glukosa atau glikogen secara anaerobik. Pada sistem ini mampu menyediakan energi untuk aktivitas 30 detik sampai 1.5 menit. Pada permainan olahraga, setelah cadangan ATPCP habis dan tidak tersedia oksigen yang cukup, pembentukan ATP masih dapat dilakukan dengan cara pemecahan glikogen, yang sering disebut glikolisis anaerobik. Energi yang dikeluarkan digunakan membentuk ATP kembali dan dihasilkan 2 ATP, dari 1 mol glukosa (180 gram) sebenarnya menghasilkan 4 mole ATP, tetapi 2 mol ATP terpakai pada proses glikolisis anaerobik. Reaksi total alur glikolisis adalah sebagai berikut:

$$
\begin{aligned}
& \mathrm{C}_{6} \mathrm{H}_{12} \mathrm{O}_{6}+2 \mathrm{NAD}^{+} \rightarrow 2 \mathrm{C}_{3} \mathrm{H}_{4} \mathrm{O}_{3}+2 \mathrm{NADH}+2 \mathrm{H}^{+}+\text {energi } \\
& \text { Glukosa } \quad \text { asam piruvat } \\
& 2 \mathrm{ADP}+2 \mathrm{H}_{3} \mathrm{PO}_{4}+\text { energi } \rightarrow 2 \mathrm{ATP}+2 \mathrm{H}_{2} \mathrm{O}
\end{aligned}
$$

NADH yang terbentuk harus dioksidasi kembali agar glikolisis tidak berhenti. Dalam keadaan cukup oksigen (aerobik) hal ini terlaksana dengan pertolongan oksigen $\left(\mathrm{O}_{2}\right)$. Bila oksigen tidak tersedia dengan cukup (anaerobik) maka NADH akan bereaksi dengan asam piruvat menghasilkan laktat dengan reaksi sebagai berikut: 


$$
\begin{aligned}
& \mathrm{C}_{3} \mathrm{H}_{4} \mathrm{O}_{3}+\mathrm{NADH}+\mathrm{H}^{+} \quad \mathrm{C}_{3} \mathrm{H}_{6} \mathrm{O}_{3}+\mathrm{NAD}^{+} \\
& \text {Asam piruvat } \\
& \text { Laktat }
\end{aligned}
$$

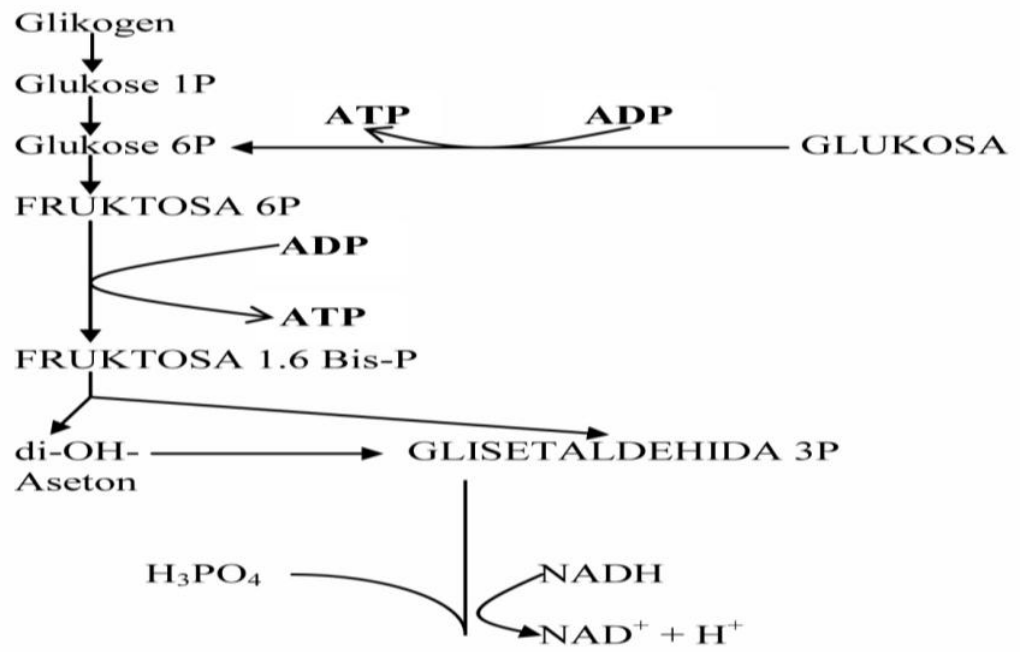

(2) 1.3 bis P-Gliserat

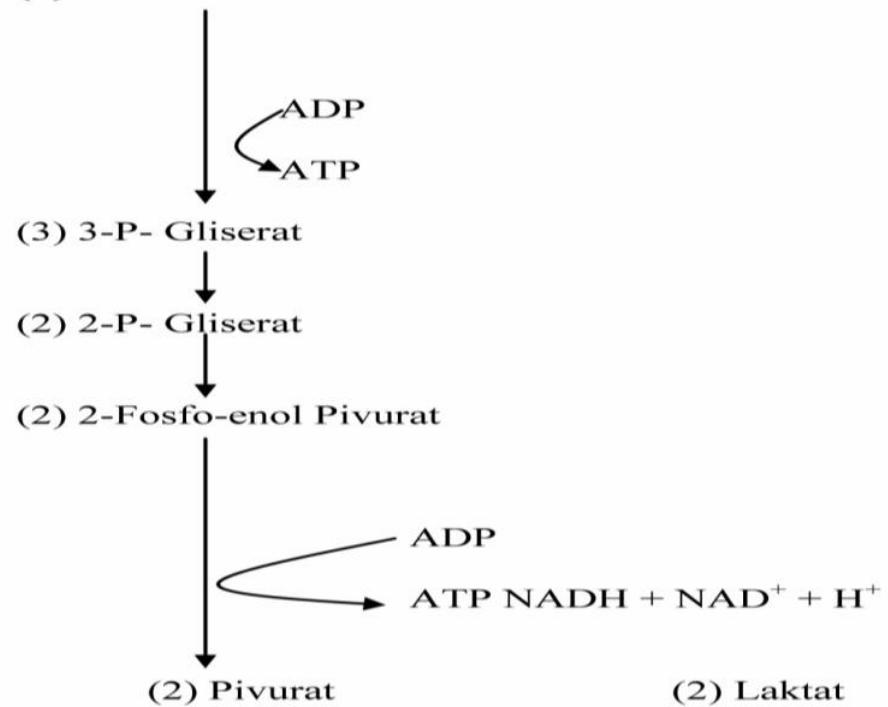

Gambar 2 Glikolisis Anaerobik (Mayes, 1985:187)

Bila laktat yang terbentuk dalam proses ini banyak maka akan mengakibatkan $\mathrm{pH}$ dalam otot maupun darah akan rendah. sehingga akan 
menghabat reaksi kimia yang menimbulkan kelelahan. Seperti halnya sistem fosfagen, glikolisis anaerobik sangat penting bagi kita selama melakukan aktivitas fisik, karena glikolisis anaerobik juga memasok ATP relatif cepat

Sistem glikolisis anaerobik dapat disimpulkan sebagai berikut:

a. Menyebabkan terbentuknya laktat yang dapat menyebabkan kelelahan.

b. Tidak membutuhkan oksigen.

c. Hanya menggunakan karbohidrat.

d. Memberikan energi untuk resistesis 2 ATP untuk setiap mol glukosa .

\subsection{Sistem Oksigen (Sistem Aerobik).}

Sistem ini terdiri dari dua bagian, yaitu glikolisis aerobik dan oksidasi piruvat. Kedua bagian dari sistem ini menggunakan siklus Krebs sebagai alur akhir berasama (final comman pathway). Sistem ini mampu menyediakan energi untuk aktivitas lebih dari 3 menit.

Namun, pada permainan olahraga hanya sedikit energi yang diperoleh melalui sistem Aerobik, hal itu disebabkan karena semua aktivitas pada permainan olahraga secara dominan dilakukan dengan itensitas yang sangat tinggi dan setiap gerakan dilakukan dengan kecepatan yang tinggi pula dalam waktu yang sangat singkat.

\section{Sistem Energi pada saat istirahat}

Pada saat istirahat kebutuhan energi jauh lebih sedikit dibandingkan pada saat aktivitas fisik. Pada saat istirahat, energi hanya diperlukan untuk mempertahankan fungsi-fungsi tubuh. Misalnya respirasi, peredaran darah, dan metabolisme. Untuk keperluan itu pasokan oksigen sudah tercukupi sehingga sistem energi yang digunakan adalah sistem energi aerobik.

Pada latihan fisik energi yang diperlukan akan bertambah karena di samping untuk mempertahankan fungsi-fungsi tubuh diperlukan tambahan energi untuk latihan itu sendiri. Penambahan energi tersebut dapat dilaksanakan dengan menggunakan sistem energi aerobik maupun anaerobik.

Bila digunakan sistem energi aerobik maka diperlukan penambahan pasokan $\mathrm{O}_{2}$, namun penambahan pasokan $\mathrm{O}_{2}$ ini akan memerlukan waktu, karena memerlukan adaptasi sistem respiratori dan sistem kardiovaskuler.

Bila latihan tersebut terjadi dengan intensitas tinggi dan dalam jangka waktu pendek maka peningkatan pasokan $\mathrm{O}_{2}$ belum terpenuhi sehingga terpaksa digunakan sistem energi anaerobik.

Pada saat istirahat tidak memerlukan gerakan-gerakan yang cepat, sehingga pasokan energi dapat dipenuhi melalui sistem aerobik. Pada saat 
istirahat kira-kira 2/3 dicukupi dengan pembakaran lemak dan sepertiganya dicukupi dari karbohidrat (Fox, 1988).

\section{Laktat}

Laktat merupakan intermediate product dari metabolisme glukosa (Mattner, 1988). Laktat merupakan produk akhir dari metabolisme anaerobik, proses ini ber-langsung tanpa adanya oksigen. Kadar laktat darah orang sehat dalam keadaan istirahat sekitar 1-1.8 mM/L (Fox, 1988).

Pada permainan olahraga dengan intensitas tinggi otot berkontraksi dalam keadaan anaerobik, sehingga penyediaan ATP terjadi melalui proses glikolisis anaerobik. Hal ini mengakibatkan meningkatnya kadar laktat dalam darah maupun otot. Ketinggian konsentrasi laktat pada darah dan otot setelah latihan tidak diketahui dengan pasti pada manusia, diperkirakan mencapai diatas $20 \mathrm{mM} / \mathrm{L}$ darah dan $25 \mathrm{mM} . \mathrm{Kg}^{-1} /$ berat otot basah, bahkan konsentrasi laktat pada darah dapat mencapai diatas $30 \mathrm{mM} / \mathrm{L}$ pada latihan dinamis dengan intensitas tingggi, sedangkan pada kuda rata - rata mencapai diatas $35 \mathrm{mM} / \mathrm{L}$ pada darah dan $25-55 \mathrm{mM} / \mathrm{Kg}^{-1}$ otot basah pada lari dengan kecepatan maksimal pada jarak $620 \mathrm{~m}$. Sedangkan pada latihan yang melelahkan selama 5 menit mencapai $200 \mathrm{mg} / 100 \mathrm{ml}(22 \mathrm{mM} / \mathrm{L})$. Laktat yang terbentuk pada waktu latihan fisik yang berat akan masuk kedalam darah dan banyaknya laktat yang masuk sebanding dengan tingginya kadar laktat dalam otot.

Permainan olahraga yang menggunakan intensitas tinggi memerlukan peningkatan pasokan $\mathrm{O}_{2}$. Peningkatan pasokan $\mathrm{O}_{2}$ dapat dicapai melalui penyesuaian sistem respirasi (untuk meningkatkan pemasukan $\mathrm{O}_{2}$ melalui paru) dan sistem kardiovaskuler (untuk meningkatkan pengangkutan $\mathrm{O}_{2}$ ke jaringan otot). Penyesuaian ini memperlukan waktu sehingga pada latihan intensitas tinggi, penyesuaian tersebut tidak tercapai selama latihan berlangsung yang selanjutnya berakibat kekurangan pasokan $\mathrm{O}_{2}$.

Selama glikolisis anaerobik konsentrasi laktat dalam sel otot meningkat. Peningkatan laktat menurunkan $\mathrm{pH}$ dari sel (konsentrasi di dalam sel lebih asam dibanding di luar sel). Enzim-enzim dalam sel sangat sensitif terhadap $\mathrm{pH}$, apabila $\mathrm{pH}$ menurun maka kecepatan reaksi dari enzim menurun, sehingga menurunkan kemampuan metabolis-me dan produksi ATP. Pada tingkat keasaman tertentu enzim-enzim glikolisis yang sensitif kehilangan daya katalisisnya dan pembentukan ATP melambat atau berhenti. Otot kehabisan tenaga dan berhenti bekerja (Mattner, 1988). Salah satu enzim glikolisis yang terhalang kerjanya akibat rendahnya $\mathrm{pH}$ intraseluler adalah fosfofruktokinase (PFK) (Fox, 1988). 
Efek yang merugikan dari peningkatan laktat ini akan ditanggulangi dengan dua cara :

a. Sistem buffer di dalam sel terutama protein di dalam sel untuk mempertahankan keadaan $\mathrm{pH}$ darah.

b. Bila kadar laktat di dalam sel cukup tinggi, laktat akan berdifusi keluar dari sel masuk ke darah, selama aliran darah ke otot yang aktif mencukupi sehingga penumpukan laktat dalam sitosol dapat dicegah.

Laktat yang masuk ke dalam darah selanjutnya akan digunakan :

a. Untuk di oksidasi dalam sel -sel otot aerobik dalam tubuh yaitu : sel otot yang kurang aktif seperti misalnya otot lengan selama bersepeda, atau pada pemain sepak bola, serta otot yang mengandung banyak mitokondria dan pembuluh darah kapiler (otot yang banyak mengandung serat "slow twitch"). Laktat tersebut akan dirubah menjadi asam piruvat yang kemudian masuk ke siklus Krebs untuk dioksidasi secara aerobik.

b. Untuk diresintesis menjadi glukosa melalui proses enzimatik yang disebut gluko-neogenesis terutama dalam sel hati.

\section{Kesimpulan}

Ditinjau secara utama dan keseluruhan, olahraga olahraga menggunakan sistem energi anaerobik yang berasal dari ATP-PC sebesar 70 $\%$. Sistem ATP - CP hanya mampu menyediakan energi untuk aktivitas kurang dari 30 detik. Pada permainan olahraga, sistem energi ATP-CP dapat dilihat hampir pada semua aktivitas seperti: smash, forehand, backhand, steping atau melangkah, dan service. Semua aktivitas pada permainan olahraga secara dominan dilakukan dengan frekuensi yang tinggi, itensitas yang sangat tinggi dan setiap gerakan dilakukan dengan kecepatan yang tinggi pula dalam waktu yang sangat singkat.

Pada permainan olahraga, setelah cadangan ATP-CP habis dan tidak tersedia oksigen yang cukup, pembentukan ATP masih dapat dilakukan dengan cara pemecahan glikogen, yang sering disebut glikolisis anaerobik. Sistem ini menyediakan ATP dari pemecahan glukosa atau glikogen secara anaerobik. Pada sistem ini mampu menyediakan energi untuk aktivitas 30 detik sampai 1.5 menit.

\section{Daftar Pustaka}

Brooks GA and Fahey TD,1987.Exercise Physiology: Human bioenergetics and its applications, New York: John Willey \& Sons. 
Mattner DR,1988. Physiology of Exercise. Second Edition, New York: Mc Millan Pub Company.

Fox EL,1988. The Physiological basis of physical education and athletics. Souders College Publishing. 